\title{
COMMON PROPERTY WASTELAND-USE PLANNING FOR SUSTAINABLE RESOURCE DEVELOPMENT IN RAMGAD CATCHMENT, KUMAUN HIMALAYA
}

\author{
C.S. Bohra*, B.S. Jina**, P. Sah** and M.D. Bhatt*** \\ *Department of Forestry, D.S.B. Campus, Kumaun University, Nainital-263002, Uttarakhand, India. \\ **Department of Botany, D.S.B. Campus, Kumaun University, Nainital-263002, Uttarakhand, India. \\ ***Department of Botany, Siddhanath Science Campus , Mahendranagar, T.U., Nepal.
}

\begin{abstract}
The Lesser Himalayan region is the most densely populated area of all the Himalayan ranges and deserves specific and adequate attention for the development of its scarce and precious common property wasteland resource in view of the fact that a large number of rural poor households in the region depend on common property wastelands for the fulfillment of their own basic needs, such as, fodder, fuel-wood, grazing etc. Of late, the region is experiencing extensive environmental problems like deforestation, landslides, soil erosion, owing mainly to the over-utilization of common property resources. This is consequent to the misuse and mismanagement of the common property land resources by villagers in Himalayan region. This paper attempts to evolve an optimal wasteland use framework for the Ramgad catchment situated in the Lesser Himalayan ranges of district Nainital located in the Himalayan state of Uttarakhand. Recognizing the drastic changes that have taken place in traditional common property wasteland use, the watershed area has been proposed to be marked for fodder development, horticultural development and medicinal plant conservation.
\end{abstract}

Key words: Wasteland; Natural resource; Households; Kumaun Himalayas.

\section{INTRODUCTION}

In the mountain ecosystem, a large proportion of basic resource needs of rural population, such as fuel, fodder grazing, etc. is fulfilled at village level mostly from the common property wasteland resource in the catchment. However, during the recent past, the region has experienced extensive environmental problems, such as, deforestation, landslides, soil erosion, etc. mainly due to the over-utilization of common property resources. The common property land resources are always misused and mismanaged because of the irresponsible attitude of the villagers in Himalayan region. It is, therefore, imperative to evolve an integrated and comprehensive framework for planning, management and sustainable development of common property wasteland resources in the Himalayas.

The main objective of this paper is to evolve an optimal wasteland use framework for the Ramgad catchment situated in the Lesser Himalayan range of district Nainital of the newly carved Himalayan state of Uttarakhand. A detailed study of the traditional common property wasteland use, regional utilization system and areas prone to privatization was made throughout the watersheds, through the preparation of large scale cadastral record maps, field survey and topographical sheets. The systematic approach for the identification of wasteland was adopted by NRSA (1986) using cadastral maps. Himalaya is one of the most geo-dynamically unstable, ecologically under-developed mountain regions of the world. The Lesser Himalayan region has been the most densely populated area of the entire Himalayan ranges deserving specific and adequate attention for the development of its scarce and precious common property wasteland resource because a large number of rural poor households depend on common property wasteland for the fulfillment of their own basic needs such as, fodder, fuel-wood, grazing, etc. in the region.

\section{MATERIALS AND METHODS}

\section{The Study Area}

The Ramgad catchment, the sample area of present investigation, is situated between $29^{\circ} 30^{\prime}$ North latitude and $79^{\circ} 40^{\prime}$ and $79^{\circ} 45^{\prime}$ East longitude, encompassing a geographical area of 75.8 $\mathrm{km}^{2}$ in the Nainital District of Kumaun Himalaya (Fig. 1.1). Out of the total common property resource area of the catchment, 91.93\%, 3.01\% and 5.06\%, are respectively under barren land, rocky wasteland and steep slopes land. From the census records, the total cattle population of the watershed is 9191 distributed in 24 villages; it has been observed that the entire region has been undergoing a process of rapid privatization of common property wasteland and land use changes.

Author for Correspondence: Dr. M. D. Bhatt Department of Botany, Siddhanath Science Campus, Mahendranagar, T.U., Nepal. Email: bhattmd@rediffmail.com. 


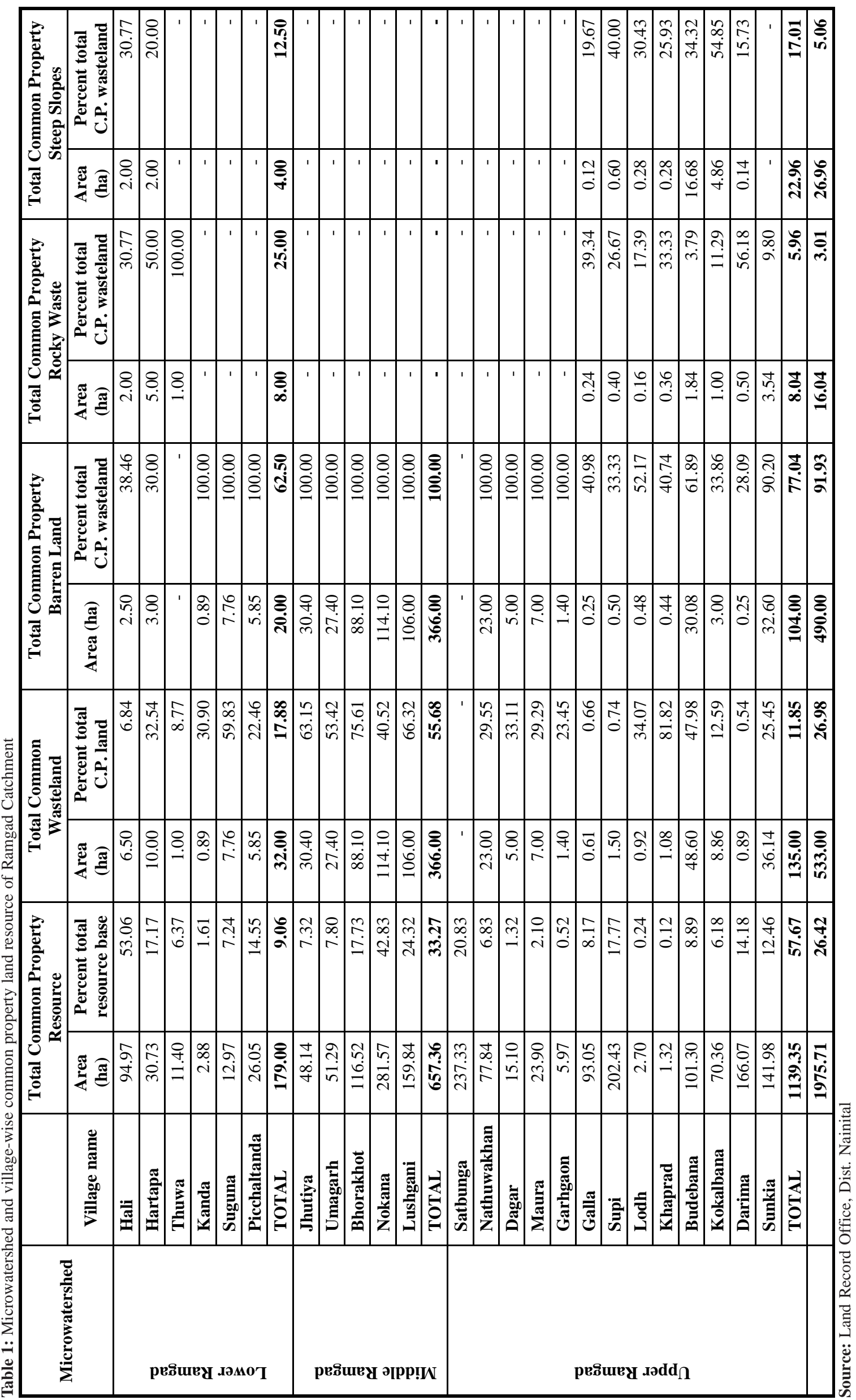




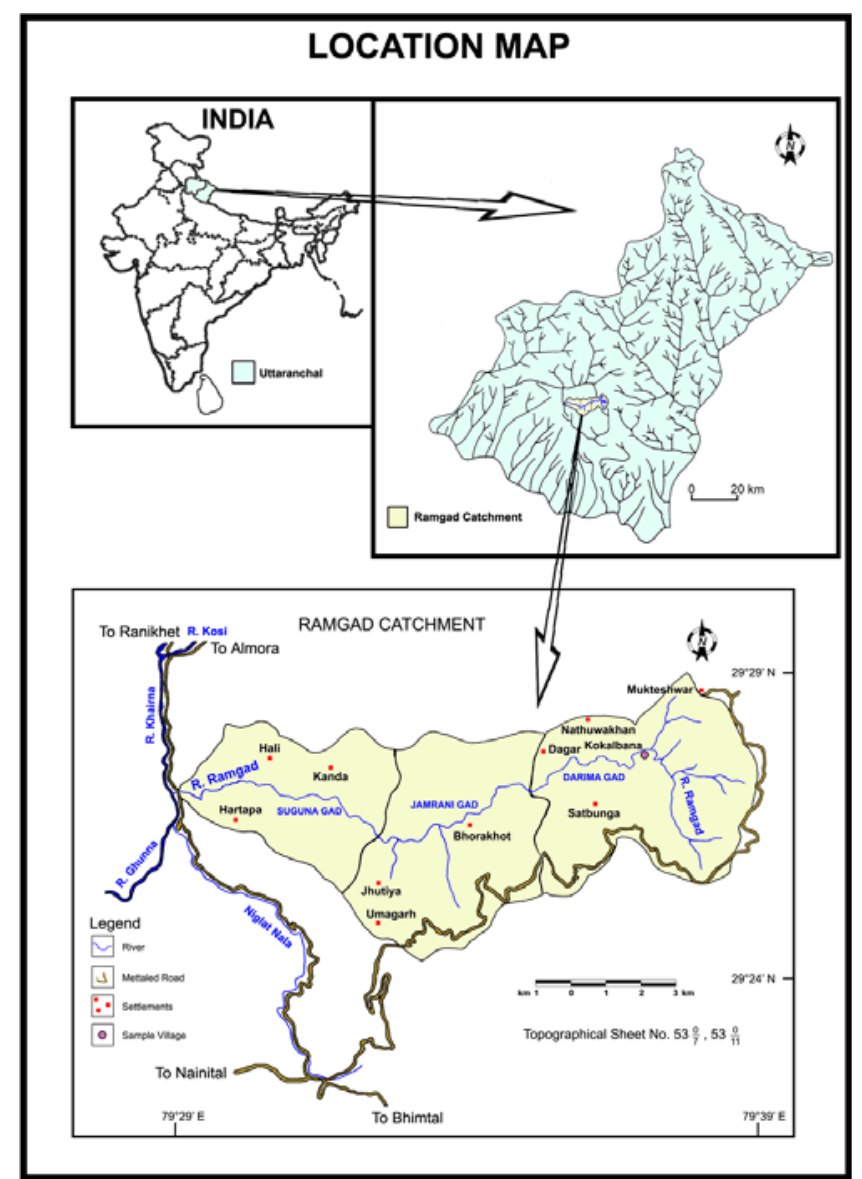

Figure1.1: Ramgadh Catchment Area in Kumaun Himalaya, India

The entire watershed was divided into three micro watersheds following the stream ordering techniques (Strahler, 1965). The delineation of common property wasteland base maps was done using the Survey of India Topographical Sheet of the area at scale 1:50,000 and remote sensing techniques were employed for the identification and classification of the wasteland. LISS-III and PAN data of Indian Remote Sensing Satellite/1-C (IRS/1C) of 25 March 2002 was used for this purpose and also through primary and secondary information collection from various government offices.

\section{RESULTS}

In the Ramgad watershed the wasteland area is quite large, constituting 27 percent of the total common property resource base of the watershed. The wasteland area includes barren land, rocky wasteland, and steep sloping land. The highest percent of wasteland in watershed (55.68\%) was recorded in Middle Ramgad watershed, followed by the Lower Ramgad (17.88\%) and Upper Ramgad microwatersheds (11.85\%) (Table 1 ). The study carried out in the Ramgad watershed has brought out the following facts regarding the common property wasteland:

Barren land: Barren land accounts for the largest proportion of total common property wasteland resource base of the watersheds. The largest proportion of barren land is present (100\%) in Middle Ramgad watershed followed by Upper Ramgad (77.04\%) and Lower Ramgad. (62.50\%). In the catchment, the barren land is mostly under pasture and grasslands, which has bee degraded by natural as well as anthropogenic pressure (Table 1).

Rocky waste: Out of the total common property resource base of the region, only $3.01 \%$ is under common property rocky wasteland, and cannot be brought under resource development programmes (Table 1 ).

Steep sloping wasteland: These are very common type of wasteland found in mountain environments. Owing to the steep slopes these areas are not easily accessible and highly prone to erosion and landslides, and are therefore, not suitable for resource development activities.

All the three categories of wasteland in the region are currently being primarily utilized as grazing area, depending upon the geographical condition, season, and local rules and traditions; protected grasslands. They also serve as open/community grasslands, fuel-wood collection areas, and stone and plaster-soil quarries (Table 1).

\section{Privatization of Common Property Natural Resources}

It was observed during the field investigations that there have been several types of encroachments on common property natural resources in the region. The important types of encroachments that have occurred in the catchment are: (i) encroachment on barren land, pastures and other categories of common lands including forests for cultivation; (ii) encroachment for non-agricultural uses, such as, residential, industry etc.; (iii) encroachment for stone quarries and removal of soils and building stones; and (iv) encroachment of common property land and forests adjacent to the land allotted by the government for agriculture, house construction, industry, school, etc. A detailed study carried out in village Nokana (with total

Table 2: Microwatershed-wise privatisation of common property wasteland in Ramgad Catchment (only barren land of the wasteland was privatised).

\begin{tabular}{|c|c|c|c|c|c|c|c|}
\hline \multirow{2}{*}{$\begin{array}{c}\text { Micro- } \\
\text { watershed }\end{array}$} & \multirow{2}{*}{$\begin{array}{l}\text { Village } \\
\text { name }\end{array}$} & \multirow{2}{*}{$\begin{array}{c}\text { Total } \\
\text { Common Property } \\
\text { Wasteland (ha) } \\
\end{array}$} & \multirow{2}{*}{\begin{tabular}{|c|} 
Common Property \\
Wasteland (ha) privatised \\
during last 20 years
\end{tabular}} & \multicolumn{3}{|c|}{ Purpose of privatisation } & \multirow[t]{2}{*}{ Other use } \\
\hline & & & & Agriculture & Temple & School & \\
\hline Lower Ramgad & - & - & - & - & - & - & - \\
\hline \multirow{2}{*}{$\begin{array}{l}\text { Middle } \\
\text { Ramgad }\end{array}$} & Nokana & 114.10 & 15.82 & 15.20 & 0.21 & 0.41 & 82.46 \\
\hline & Bhorakhot & 106.00 & 12.53 & 12.11 & 0.17 & 0.25 & 80.94 \\
\hline Upper Ramgad & Budebana & 48.60 & 09.27 & 8.50 & 0.15 & 0.62 & 30.06 \\
\hline \multicolumn{2}{|c|}{ Ramgad Catchment } & 268.70 & 37.62 & 35.81 & 0.53 & 1.28 & 193.46 \\
\hline
\end{tabular}

Source: Land Record Office, Dist. Nainital. 
Table 3: Microwatershed and village-wise grazing pressure on common property resource in Ramgad Catchment.

\begin{tabular}{|c|c|c|c|c|}
\hline Microwatershed & Village name & $\begin{array}{c}\text { Common property } \\
\text { wasteland (ha) }\end{array}$ & $\begin{array}{l}\text { Cattle } \\
\text { units }\end{array}$ & $\begin{array}{c}\text { Grazing pressure } \\
\text { (ha/ cattle) }\end{array}$ \\
\hline \multirow{7}{*}{ Lower Ramgad } & Hali & 6.50 & 523 & 0.01 \\
\hline & Hartapa & 10.00 & 585 & 0.02 \\
\hline & Thuwa & 1.00 & 61 & 0.02 \\
\hline & Kanda & 0.89 & 88 & 0.01 \\
\hline & Suguna & 5.85 & 87 & 0.07 \\
\hline & Picchaltanda & 7.76 & 71 & 0.11 \\
\hline & TOTAL & 32.00 & 1415 & 0.02 \\
\hline \multirow{6}{*}{ Middle Ramgad } & Jhutiya & 30.40 & 492 & 0.06 \\
\hline & Umagarh & 27.40 & 80 & 0.34 \\
\hline & Bhorakhot & 88.10 & 632 & 0.14 \\
\hline & Nokana & 114.10 & 459 & 0.25 \\
\hline & Lushgani & 106.00 & 419 & 0.25 \\
\hline & TOTAL & 366.00 & 2082 & 0.18 \\
\hline \multirow{14}{*}{ Upper Ramgad } & Satbunga & 0.00 & 790 & 0.00 \\
\hline & Nathuwakhan & 23.00 & 558 & 0.04 \\
\hline & Dagar & 5.00 & 33 & 0.15 \\
\hline & Maura & 7.00 & 229 & 0.03 \\
\hline & Garhgaon & 1.40 & 221 & 0.01 \\
\hline & Galla & 0.61 & 242 & 0.00 \\
\hline & Supi & 1.50 & 919 & 0.00 \\
\hline & Lodh & 0.92 & 205 & 0.00 \\
\hline & Khaprad & 1.08 & 0 & 0.00 \\
\hline & Budebana & 48.60 & 593 & 0.08 \\
\hline & Kokalbana & 8.86 & 133 & 0.07 \\
\hline & Darima & 0.89 & 956 & 0.00 \\
\hline & Sunkia & 36.14 & 815 & 0.04 \\
\hline & TOTAL & 135.00 & 5694 & 0.02 \\
\hline \multicolumn{2}{|c|}{ Ramgad Catchment } & 533.00 & 9191 & 0.06 \\
\hline
\end{tabular}

Source: Land Record Office, Dist. Nainital.

114.1 ha common land) and Bhorakhot (with total 106 ha common land) of Middle Ramgad Microwatershed and Budebana (with total 48.60 ha common land) of Upper Ramgad Microwatershed revealed that 15.8 ha, 12.5 ha and 9.3 ha, respectively common land of these villages has been encroached upon for agriculture and various other purposes during the last 15-20 years (Table 2).

\section{DISCUSSION}

The common property wasteland in the Himalayan region of India is mainly composed of cultivated wasteland and common property wasteland. These components play a very significant role in maintaining the economy of the region. In most of other parts of the country the rural communities, particularly, the marginalized groups, landless households and rural poor are heavily dependent on these lands for grazing their cattle, fuel-wood and fodder collection, and for fulfilment of their various other resource needs. Most of the farming systems in the region are at the subsistence level and have evolved over the years by the trial and error method by the farmers to meet their needs of food, fodder, fuel wood and timber (Shah 1982, Singh et al. 1984).

\section{Privatization of Common Property Natural Resources}

Privatization of common property natural resources is one of the most important processes responsible for the degradation and depletion of common pool resources in the region. This kind of encroachment on common lands has severely affected the sustainability of rural community, particularly, the livelihood securities of a large number of poor households who are dependent on common pool resources. The privatization of common property resources is taking place mainly because of the increasing pressure of population and the increased demand of natural resources in the rural areas. In addition to this, the institutional framework that existed for the management and use of common property resources has collapsed and the regulatory mechanism in the rural areas of the region has become permissive. At the same time, the state has taken a conscious decision to distribute uncultivated open access lands to socio-economically weaker sections of community in the village, and also to allot common lands for various other purposes under economic and political pressures of certain people. 


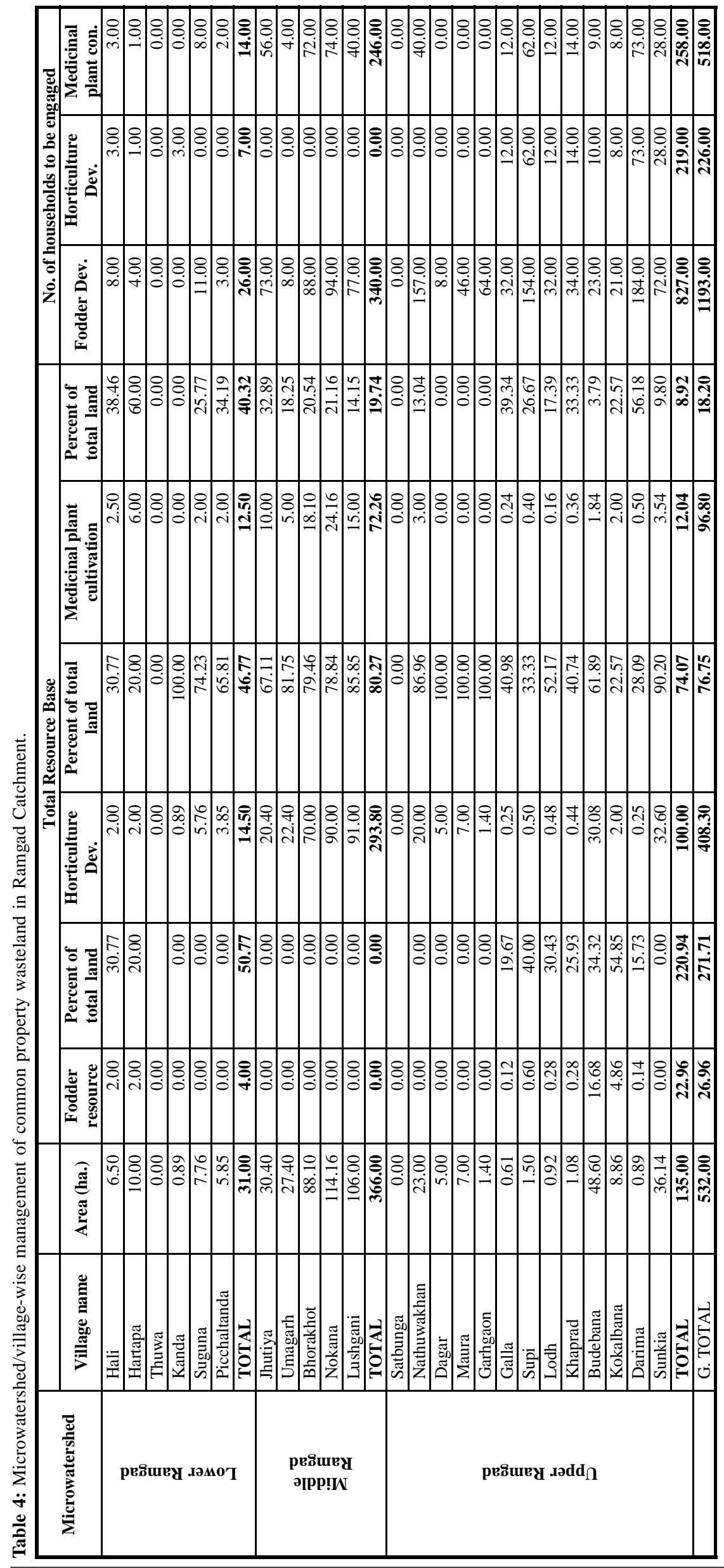

Grazing Pressure on Common Wasteland

Due to the increase in the cattle population, the pressure on common property wasteland is also increasing in the region. Consequently, availability of grazing land per capita has declined. The different categories of common property wastelands constitute the entire grazing area of the watershed. Since the practice of grazing is common in all classes of wasteland, the entire wasteland has been taken into account for developing the estimates of grazing incidence in the present study. However, the cattle are generally sent to the reserved and community forests mainly during summers and dry winters when there is very little aboveground biomass for grazing in other grazing areas. Also, the cattle of those villages in which no grazing land is available are sent to the reserved forests for grazing round the year after travelling long distances. Another feature is that the grazing is prohibited in different categories of private property wasteland during the monsoon so that the protected fodder could be harvested and stored by the owner-household after the rainy season. Similarly, most of the community forests remain open for grazing throughout the year, but some remain closed during the rainy season for the harvest of fodder. The aboveground biomass is harvested after the monsoon in the month of October and distributed among the village-households. In order to determine the incidence of grazing in the region, the livestock number were converted into cattle units adopting the conversion norm recommended by the National Commission on Agriculture (1976). After applying the conversion norm the total number of cattle in the watershed was computed to be 8549. In the present study, the calculation of grazing area has been done at village level, and only permanent grazing lands have been taken into consideration for determining the grazing pressure in the region. Considering annual average rainfall as an important factor determining the ecological sustainability of the grazing areas in different geo-environmental regions of the country, the National Commission on Agriculture has suggested $3.3-5$ cattle ha- $^{-1}$ grazing land in areas with above $1905 \mathrm{~mm}$ rainfall, 1.6 - 2.5 cattle ha $^{-1}$ in 1270 - 1905 $\mathrm{mm}, 1-12.5$ in $890-1270,0.62-0.33$ 
cattle ha ${ }^{-1}$ in $635-890 \mathrm{~mm}$, and only $0.5-0.6$ cattle ha $^{-1}$ in areas having less than $635 \mathrm{~mm}$ annual rainfall. But in the absence of rainfall statistics for a range of locations, particularly in mountain environment the criteria cannot be used for determining the incidence of grazing.

Singh et al (1984) have suggested that minimum 3.5 ha grazing land should be available for one unit of cattle in the Himalayan region. Considering this norm, there in not a single village in the study region that has grazing incidence under this ecologically permissible limit. Table 3 shows the village-wise availability of grazing area (cattle ha ${ }^{-1}$ ) in the catchment that ranges between 0.01 cattle ha $^{-1}$ and 0.34 cattle ha ${ }^{-1}$. This shows that the pressure of grazing is much higher than the recommended standard for the mountain regions. There are two villages in the watershed, which do not have any grazing area for their cattle, and the livestock of these villages either encroach upon the grazing areas of other villages that often result in community conflicts or go to the reserved forests or are found grazing along the roads passing through the villages. This shows the pressure of grazing is considerably very high, and the grazing lands are coming under increased biotic stress with the massive increase in cattle population in the region. As a result, on an average the reserved forests up to a distance of $7 \mathrm{~km}$ from the rural settlements in the region are highly degraded and depleted. The scarcity of grazing areas in the watershed has led most of the households to avoid keeping cattle, which are now either shared within the village or are hired from neighbouring villages for agricultural work. However, the number of goats is increasing because (i) the goats being smaller and lighter in weight can easily graze on the steep slopes, (ii) after grazing they do not require additional fodder and care, and (iii) goats rearing is economically more profitable practice compared to rearing other livestock.

\section{Suggestions for Recovery of Wasteland}

Horticulture Development: It has been recommended that 408.3 ha of common property land be brought under horticulture development, and 226 households of the village be engaged in this rehabilitation and management practice of wasteland in the village (Table 4). Poly-house technology can be highly useful in the development of horticulture in the region. The technology and infrastructure for growing a variety of vegetables, flowers and various types of plants is already available with Kumaon Mandal Vikas Nigam at highly subsidized cost for the rural areas. If this experiment is successful, this wasteland rehabilitation measure could be adopted in private property wasteland of the village in large scale.
Fodder Development: The headwater is currently also facing 95.14 percent scarcity of fodder. Keeping this in view, it is recommended that 1193 poor households of the watershed bring 26.96 ha steep sloping land under fodder development, and the grasses grown on the slopes would have a binding effect and control the soil/land erosion on such slopes (Table 4).

Cultivation of Medicinal Plants: The mountainous part of the State of Uttarakhand is an ideal habitat for variety of medicinal plants, and some of them are very rare. Keeping this in view, Uttarakhand government has given top priority to the conservation and cultivation of medicinal plants in the State. It was observed that a variety of medicinal plants naturally grow in the different categories of wasteland, including the rocky areas. Besides, the different types of lichens grows only on rocks. In view of this, 96.80 ha wasteland of the village have been recommended to be brought under the cultivation and conservation of medicinal plants, and 518 household of the watershed has been identified to manage this resource development practice (Table 4).

To conclude, recognizing the drastic changes that have taken place in traditional common property wasteland use, the watershed area has been proposed to be defined for fodder development (26.96 ha), horticultural development (408.3 ha) and medicinal plant conservation (96.7 ha).

\section{REFERENCES}

Bhagwati, N. 2004. Common Property Natural Resource Management in Ramgad Catchment in Kumaun Himalaya, Unpubl. Ph.D. Thesis, Kumaun University, Nainital.

Iyengar, S. and Shukla, N. 2000. Regeneration and Management of Common Property Natural Land Resources in India. A Review Programme Material of Sixth International Summer School of Management of Common Property Natural Resources, June 1019, Centre for Management in Agriculture, Indian Institute of Management, Ahmedabad.

NRSA. 1986. Nation wide wasteland mapping using Satellite Remote Sensing Data, Technical Publication, Hyderabad.

Shah, S.L. 1982. Social Economic Technological Organisational and Institutional Constraints in the Afforestation of Civil Soyam Usar and Wastelands for Resolving Fuel wood Crisis in the Hill District of U.P. Vivekananda Parvatiya Krishi Anusandhanshala, Almora, India.

Singh, J.S., Pandey, U. and Tiwari, A.K. 1984. Man and Forests: a central Himalayan case study. Ambio. 13(2):80-87.

Thimmaiah, G. 1997. Foreword in J. Parikh et al. (eds.) Sustainable Regeneration of Degraded Land, New Delhi. 